Research Journal of Applied Sciences 6 (7-12): 451-456, 2011

ISSN: $1815-932 \mathrm{X}$

(C) Medwell Journals, 2011

\title{
Solar Thermal Energy Technologies in Nigeria
}

\author{
A.A. Adeyanju \\ Department of Mechanical and Manufacturing Engineering, \\ University of the West Indies, St. Augustine, Trinidad, Nigeria
}

\begin{abstract}
The solar thermal energy resource situation in Nigeria including the estimated potential and available amount of the resource are presented in this study. The status of the database is discussed indicating its degree of adequacy and an identification of the gaps. The National Energy Policy Document states that Nigeria lies within a high sunshine belt and within the country; solar radiation is fairly well distributed. The annual average of total solar radiation varies from about $12.6 \mathrm{MJ} \mathrm{m}^{-2}$ day $\left(3.5 \mathrm{kWh} \mathrm{m}^{-2}\right.$ day) in the coastal latitudes to about $25.2 \mathrm{MJ} \mathrm{m}^{-2}$ day $\left(7.0 \mathrm{kWh} \mathrm{m}^{-2}\right.$ day) in the far North. Assuming an arithmetic average of $18.9 \mathrm{MJ} \mathrm{m}^{-2}$ day $\left(5.3 \mathrm{kWh} \mathrm{m}^{-2}\right.$ day), Nigeria therefore has an estimated 17, 459, 215.2 million MJ day ${ }^{-1}\left(17.439 \mathrm{TJ}^{-1 a y}{ }^{-1}\right.$ ) of solar energy falling on its $923,768 \mathrm{~km}^{2}$ land area. Energy is one commodity on which the provision of goods and services depend, its availability and consumption rate is an economic index to measure the development of any community. In Nigeria, there is a limitation to power supply from the National grid which has adversely affected the economic and social development of the populace. This really necessitates the need for decentralized power source as a viable alternative to which solar/thermal energy readily fits in.
\end{abstract}

Key words: Energy potentials, power supply, solar, thermal, energy, database, resource

\section{INTRODUCTION}

The Solar Thermal Energy Resource of Nigeria is the totality of the solar radiation falling on its $923,768 \mathrm{~km}^{-2}$ land area. This total solar radiation includes the direct radiation as felt on clear sunny days, diffuse radiation scattered by clouds and atmospheric gases and vapors and felt on cloudy days even when the sun is not visible. For some applications, the albedo or solar radiation reflected by the ground and surroundings of the location or solar device of interest may be included in the total solar radiation (Yumkella et al., 2003). Application of solar radiation in most solar thermal technologies is based on the totality of the shortwave, visible spectrum and long-wave radiation within the wavelength range of 0.1-100 $\mu \mathrm{m}$. A few specialized technologies however, do discriminate within certain wavelength bands such as the ultra-violet or the near infrared ranges.

Undoubtedly, the largest solar radiation and other climatologically database available in Nigeria reside with the Nigerian Meteorological Agency (NIMET) obtained from their weather stations located widely throughout the country. The data from the various stations are collated centrally at the headquarters in Oshodi, Lagos where climatological data upwards of 30 years are available. Many of the stations are airport or aerodrome weather stations. Another source of localized solar radiation data is the International Institute of Tropical Agriculture, ITA, Ibadan, Oyo state which has agro-climatological stations at its headquarters and at its agricultural substations or outstations (Yumkella et al., 2003) very good solar and other climatic database upwards of 20 years can be readily found at ITA.

Estimated resource base: The National Energy Policy Document states that Nigeria lies within a high sunshine belt and within the country; solar radiation is fairly well distributed. The annual average of total solar radiation is varies from about $12.6 \mathrm{MJ} \mathrm{m}^{-2}$ day $\left(3.5 \mathrm{kWh} \mathrm{m}^{-2}\right.$ day) in the coastal latitudes to about $25.2 \mathrm{MJ} \mathrm{m}^{-2}$ day $\left(7.0 \mathrm{kWh} \mathrm{m}^{-2}\right.$ day) in the far North. Assuming an arithmetic average of $18.9 \mathrm{MJ} \mathrm{m}^{-2}$ day $\left(5.3 \mathrm{kWh} \mathrm{m}^{-2}\right.$ day), Nigeria therefore has an estimated 17, 459, 215.2 million MJ day ${ }^{-1}\left(17.439 \mathrm{TJ} \mathrm{day}^{-1}\right)$ of solar energy falling on its $923,768 \mathrm{~km}^{2}$ land area (ECN, 2003).

The above arithmetic average may be interpreted as the application of each of the above radiation values to approximately half the area of the country, thus giving a total of $(12.6+25.2) \times(923,768 / 2)$ which gives the same value as before. Annually, the above average solar intensity is $1934.5 \mathrm{kWh} \mathrm{m}^{-2}$ year, a value that can be used to calculate the available solar energy. Thus, over a whole year, an average of 1,770 thousand $\mathrm{Twh} \mathrm{ear}^{-1}$ of solar energy falls on the entire land area of Nigeria. This is about 120 thousand times the total electrical energy generated by the National Electric Power Authority for the whole country for the year 2002 (Fagbenle, 1992a). This then is an estimated potential solar thermal energy 
resource base. Part of this resource falls on agricultural and forest lands and of course is useful for photosynthesis processes; others fall on developed areas most of which could be harnessed for power generation through roof and building-integrated solar conversion devices (solar water heaters, solar photovoltaic-PVcladdings, etc.) others fall on roads and waterways some of which are useful or useable, e.g. for drying agricultural products by rural dwellers. Thus, this total resource is largely useable or harness-able.

\section{STATUS OF DATABASE}

The solar radiation measuring stations of the Nigerian Meteorological Agency earlier discussed are mostly airport and aerodrome weather stations which were originally set up to aid civil aircraft navigation (Yumkella et al., 2003). Thus, the stations themselves cover only about thirty localities. To obtain a good solar radiation database there is need to set a lot more radiation measurement stations all over the country particularly in the Northern areas where the radiation belt is very high. Radiation studies done have relied on the data from the meteorological stations to develop equations applicable to either zones of the country or to the whole country which are useful for solar equipment manufacturers and designers. Such studies need to be validated with much more data evenly spread all over the country.

Most of the solar radiation data taken at the meteorological stations are for the total or global solar radiation. A programme on gathering data on other components of solar radiation such as diffuse radiation, normal radiation and spectral radiation also needs to be instituted as such data find use in equipment design (Fagbenle, 1992b). Furthermore although, the meteorological stations were in isolated aerodromes far from development at the time they were built $>40$ years ago, almost all the stations are now in built up areas with high probability of shading effects on the instruments. There is a need for new, purpose-built stations designed to fill knowledge gaps in a solar radiation mapping programme for the country.

\section{OVERVIEW OF SOLAR THERMAL TECHNOLOGIES}

Following the broad overview presented below, solar thermal technologies (Fig. 1) are considered in greater detail under the following three broad categories as Table 1 shows:

- Proven, mature and commercial stage

- Proven, mature but largely demonstration stage

- Proven but immature development-stage

For each of these categories, the technical characteristics, economic competitiveness and the benefits and limitations of each technology are examined (ECN, 2003).

Solar thermal technologies available in the international market today are efficient and highly reliable, delivering solar energy in a wide range of applications, among which are domestic hot water and space heating in residential and commercial buildings, swimming pool heating, solar-assisted cooling, solar-assisted district heating, industrial process heat, desalination, agricultural products drying, hatcheries, chick brooders and seed germinators, solar cooking and electric power generation. In Nigeria, the Energy Commission of Nigeria with its two renewable energy centers, namely, the National Center for Energy Research and Development, NCERD at the University of Nigeria, Nsukka and the Sokoto Energy Research Center, SERC at Usmanu Danfodiyo University,

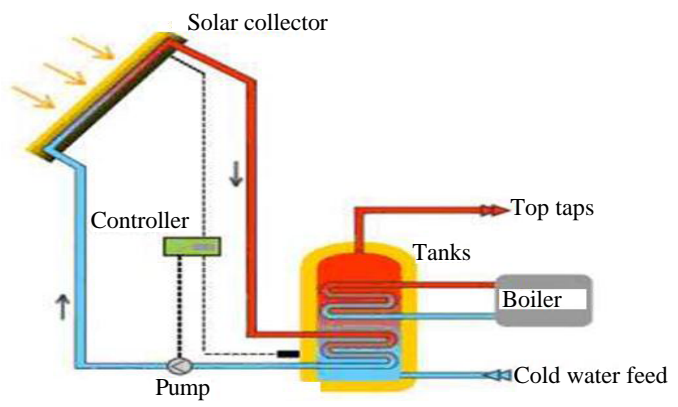

Fig. 1: Solar thermal technology

Table 1: Classification of solar thermal technologies by stage of development (ECN, 2003)

\begin{tabular}{|c|c|c|}
\hline Proven mature and commercial & Proven mature but largely demonstration & Proven but largely developmental \\
\hline Solar water and air heating & Solar stills & Solar furnace and very high temp. heating \\
\hline Swimming pool solar heating & Solar desalination & $\begin{array}{l}\text { Desalinationphotovoltaic thermal (photovoltaic- } \\
\text { thermal composite systems) }\end{array}$ \\
\hline Heat pump solar heating & Solar drying & Solar ejector cooling \\
\hline Solar cooking & Solar brooding Incubation, etc. & Solar ponds \\
\hline Solar passive architecture & $\begin{array}{l}\text { Solar pasteurization and sterilization. Solar refrigeration and cooling } \\
\text { (absorption systems and adsorption systems). Solar desiccant cooling } \\
\text { solar thermal electricity (parabolic trough) systems; parabolic dish } \\
\text { systems; central receiver power tower systems }\end{array}$ & \\
\hline
\end{tabular}


Sokoto has developed or adapted a variety of renewable energy technologies and capacities including solar dyers, solar water heaters, solar cookers and solar chick brooders (Yumkella et al., 2003). Many tertiary institutions have also developed or adapted several solar thermal technologies for local use.

These local developments need to get from the present largely demonstration or dissemination stage to the next stage of commercialization with private sector driven but high profile public sector led initiatives.

\section{ECONOMIC COMPETITIVENESS OF SOLAR THERMAL TECHNOLOGIES}

Most of the solar thermal technologies are economically competitive even in developed countries of the world where the market is fully developed and private-sector driven. The competitiveness of solar water heating for commercial and institutional water heating has been demonstrated for Nigeria in previous studies. However, the Solar Thermal Power (STP) generation technologies are at present economically uncompetitive.

The market success of STP plants has been found to depend heavily on the choices made between environmental protection and the lowest possible electricity cost. The final outcome will undoubtedly depend on both energy policy decisions and international support for responsible environmental actions in a climate of scarce resources. A study of the electricity cost for market introduction of STP technologies with initial subsidies has shown that competitive markets are achievable as from 2010 at about 4-6 US\& $\mathrm{kWh}^{-1}$ for intermediate load power. Sustained global markets for STP is expected between 2015 and 2020 during which period the total installed capacity would have increased from the present level of just 354 to $>5000$ MW. A Greenpeace-European Solar Thermal Power Industry Association (ESTIA) study has projected 21,540 MW installed solar thermal power capacity by 2020 with a total investment of about US $\$ 42$ billion (European Commission, 2001).

\section{BENEFITS AND LIMITATIONS OF SOLAR THERMAL ENERGY}

Solar thermal energy is all benefits as far as environmental pollution is concerned. Its limitations include lack of enabling environment for the various solar thermal technologies to become competitive with the fossil energy technologies which have long enjoyed entrenched subsidies and huge technology and market investments. The initial cost of some solar thermal technologies such as solar water collectors is unaffordable to large segments of the many developing economies without public sector intervention.

\section{MARKET SITUATION FOR SOLAR THERMAL ENERGY TECHNOLOGIES}

Thermal energy is used daily in most sectors of the economy in the domestic/residential sector for cooking, heating bath water and washing in the commercial/ institutional sectors for cooking, heating bath water and washing in cafeterias, hotels, schools, hospitals, clinics, government buildings, etc. in the agricultural sector for drying agricultural crops and grains, spices, fish, etc. in the industrial sector for heat energy in industrial processes e.g., in the following industries: tobacco, textiles, vegetable oils, beverages, pharmaceuticals, leather, cement, breweries, etc.

Present thermal energy demand and supply situation: There is very little public awareness of the tremendous solar thermal energy resource available for utilization in many sectors of the economy; domestic/residential, commercial, industrial, government/institutional and agriculture.

Consequently, there is a corresponding lack of demand for and supply of solar thermal technologies in the large thermal energy market. Solar thermal energy market share in the overall thermal energy market is therefore nil in all areas/segments of the market. The market is yet to be created from the present largely demonstration stage of solar thermal technologies in the country.

Table 2 shows a sectoral thermal energy demand in Pica Joules (PJ) based on several sources. The estimates under Agriculture/Rural Development were based on information from several sources among which are the Biomass chapter of this report and ECN study reports. The thermal energy demand totals for the target years 2007,2015 and 2025 are 392, 605 and 810 PJ, respectively as shown in Table 2 and 3 . In the business as usual scenario, these will be met mainly by fossil fuels including electricity from fossil fuels and biomass (fuel wood mainly).

The ECN has made projections of the total final energy demand in Nigeria by sectors till the year 2030 for each of the three scenarios: the Reference Scenarios (RS), the High Growth Scenario (HGS) and the Low Growth 
Res. J. Applied Sci., 6 (7-12): 451-456, 2011

Table 2: Sectoral thermal energy demand estimate (ECN, 2003)

\begin{tabular}{|c|c|c|c|c|}
\hline Sectors & $19902007^{*}$ & $20102015^{*}$ & $2025^{*}$ & 2030 \\
\hline Domestic/Residential & 120.4 & 220.9 & - & 384.50 \\
\hline Cooking & 71.7 & 121.5 & - & 190.90 \\
\hline Non Substitutable Electricity (NSE) & 8.6 & 20.5 & - & 45.60 \\
\hline Thermal component of NSE (20\%) & 1.72 & 4.1 & - & 9.12 \\
\hline Thermal sub-total, domestic & $73.42,117.773$ & $125.6,144.21$ & 181.420 & 200.02 \\
\hline Commercial & 16 & 50.6 & - & 160.90 \\
\hline Cooking & 0.6 & 19 & - & 1.90 \\
\hline NSE & 12.3 & 39.4 & - & 126.60 \\
\hline Thermal component of NSE ( $20 \%)$ & 2.46 & 7.88 & - & 25.32 \\
\hline Thermal sub-total, commercial & $3.06,7.134$ & $8.88,13.465$ & 22.635 & 27.22 \\
\hline Agricultural/Rural development & 5.51 & 9 & - & 16.00 \\
\hline Drying & 2 & 4 & - & 6.00 \\
\hline Dairy, pasteurization, etc. & 0.1 & 1.5 & - & 4.00 \\
\hline Chick brooding, egg incubation & 0.01 & 0.5 & - & 2.00 \\
\hline Thermal sub-total, agriculture/R.D. & $2.11,4.833$ & $6,67.5$ & 10.500 & 12.00 \\
\hline \multicolumn{5}{|c|}{ Government/Instituional/Hospitals, hotels, clinics, schools, health centres, etc. } \\
\hline Cooking, water heating, etc. & 90 & 150 & - & 300.00 \\
\hline Distillation, sterilization, desalination & 2 & 10 & - & 20.00 \\
\hline NSE & 8 & 40 & - & 80.00 \\
\hline Thermal sub-total, govt./instituional & 100,170 & 200,250 & 350.000 & 400.00 \\
\hline Industrial & 86 & 215.9 & - & 372.90 \\
\hline Process heat & 59.6 & 156 & - & 252.10 \\
\hline NSE & 2.1 & 6.7 & - & 21.30 \\
\hline Thermal sub-total, industrial & $61.7,92$ & $162.7,190.38$ & 245.730 & 273.40 \\
\hline Thermal energy grand total & $240.29,391.74$ & $503.18,605.55$ & 810.280 & 912.64 \\
\hline Thermal energy grand total in TWh & $66.747,108.817$ & $139.77,168.21$ & 225.080 & 253.51 \\
\hline Thermal energy grand total in GWh & 66747,108817 & 139772,168207 & 225076.000 & 253511.00 \\
\hline Total thermal energy & - & -2128 & 248869.000 & - \\
\hline Demand in GWh by ECN & 193789 & - & - & - \\
\hline
\end{tabular}

Table 3: Total thermal energy demand by scenario (*Target years) (ECN, 2003)

\begin{tabular}{lrrrrrrr}
\hline \multicolumn{2}{l}{ Total } & 2000 & $2007^{*}$ & 2010 & $2015^{*}$ & 2020 & 2025 \\
\hline Total thermal energy demand (PJ) & 329.38 & 391.74 & 503.18 & 605.55 & 707.91 & 810.28 & 912.64 \\
Total final energy demand by scenario in (PJ) & & & & & & \\
High growth & 1517.00 & 2093.8 & 2341.00 & 3183.00 & 4025.00 & 4766.00 & 5507.00 \\
Reference & 1517.00 & 2039.9 & 2264.00 & 2975.00 & 3686.00 & 4124.00 & 4562.00 \\
Low growth & 1517.00 & 2001.4 & 2209.00 & 2832.50 & 3456.00 & 3754.50 & 4053.00 \\
\hline
\end{tabular}

Table 4: Total thermal energy demand as percentage of total final energy demand (ECN, 2003)

Total thermal energy as percentage

\begin{tabular}{lllllll} 
of total final demand by scenario & 2000 & $2007^{*}$ & 2010 & $2015^{*}$ & 2020 & $2025^{*}$ \\
High growth & 21.71 & 21.56 & 21.49 & 19.54 & 17.59 & 17.08 \\
Reference & 21.71 & 22.07 & 22.23 & 20.72 & 19.21 & 19.61 \\
Low growth & 21.71 & 22.46 & 22.78 & 21.63 & 20.01 \\
\hline
\end{tabular}

${ }^{*}$ Target y ears

Scenario (LGS). Table 4 shows the thermal energy demand as a percentage of the ECN total final energy demand for each of the three scenarios from which it is seen that the thermal energy demand is about $20 \%$ of the total final energy demand regardless of the scenario within the plan horizon (ECN, 2004).

A significant proportion of this thermal demand projection could be met by solar thermal energy thus, reducing the fossil fuel required with consequent environmental, ecological, social and health benefits. An estimate of how much of the thermal energy in each sector that could be met by solar thermal collectors shows in Table 5. It is seen that solar thermal energy could contribute as much as about 7 and $9 \%$ of the HGS and
Table 5: Thermal energy demand that could be met by Solar Thermal Systems (ECN, 2003)

\begin{tabular}{lrrrrrr}
\hline Sectors & 1990 & $2007^{*}$ & 2010 & $2015^{*}$ & $2025^{*}$ & 2030 \\
\hline Domestic & 36.00 & 56.00 & 60.00 & 69.00 & 86.00 & 95.00 \\
Commercial & 0.80 & 2.00 & 2.20 & 3.40 & 5.70 & 6.80 \\
Agriculture & 1.60 & 4.10 & 4.50 & 6.00 & 7.50 & 9.00 \\
Govt//nstitution & 50.00 & 92.50 & 100.00 & 133.00 & 167.00 & 200.00 \\
/Hotel/Clinics/Schools/etc. & & & & & \\
Industry & 12.00 & 29.50 & 32.50 & 40.00 & 47.00 & 55.00 \\
Total (PJ) & 100.40 & 184.10 & 199.20 & 251.40 & 313.20 & 365.80 \\
Total (TWh) & 27.89 & 51.14 & 55.33 & 69.83 & 87.00 & 101.61 \\
\hline Target years & & & & & &
\end{tabular}

the LGS total final energy demand, respectively within the target period. Thermal energy is required in the domestic sector for boiling water for bathing and cooking as well as for cooking food. Most homes, particularly rural homes 
meet this requirement from biomass and paraffin cookers while the upper middle to the upper class use LPG and electric cookers and geysers. In the commercial sector, thermal energy is similarly used for boiling water and cooking in the informal commercial sector, biomass is the main cooking and water boiling fuel while in the formal commercial sector, both LPG and electricity are the main fuels used to meet the thermal energy needs. In the conglomerate of sectors termed Govt./Institutions/ Hospitals/Hotels/Clinics/Schools/etc., the thermal energy requirement is met by all the main types of fuel, namely, electricity, biomass, paraffin and LPG. In the industrial sector, the thermal energy requirement is met mainly by boilers and heaters using heavy fuel oil, diesel oil or natural gas.

Key drivers for solar thermal energy technology market: Solar energy can be successfully applied for heating purposes at all latitudes. Some of the strongest markets for solar thermal energy in the world are in Europe (Germany and Austria) where the average solar radiation received annually is less than that received in most sunny tropical regions. Indeed even in Europe, Germany and Austria receive considerably less sunshine than Southern European countries such as Spain, Italy and Greece and Mediterranean Cyprus and Malta yet the market in these countries lag far behind those of Germany and Austria.

The lessons learned from the successful thermal energy stories of Germany, Barcelona, Spain, India and Botswana in Southern Africa provide an insight into the important key drivers for the solar market from the decades of these national experiences as follows. Policy formulation, particularly regulations that make installation of solar thermal systems mandatory in some sectors are important. Market competitiveness of solar thermal technologies need to be improved through stable and well designed financial market incentives and financing mechanisms for investors and users by the government.

Such incentives include capital subsidies which are investment assistance in the form of grants and allowances, operational cost grants; preferential loans and guarantees and tax privileges. Duties, VAT, levies, etc., on solar thermal energy systems should be removed until the market forces can take control.

Similarly subsidies, both direct and indirect for non-renewable energy technologies and competing fossil-energy equipment and systems need to be removed. Regulatory, administrative and institutional conditions which make private sector investment difficult would need to be relaxed or scrapped.
Gaps and barriers to solar thermal technology market development: Flaws in the ways markets operate such as entrenched subsidized energy prices of fossil fuels, energy prices that do not internalize the full social, health and environmental costs and poorly informed consumers (Manohar and Adeyanju, 2009). These barriers also relate to human behavior, among which are the low priority given to saving energy by many consumers, both domestic and business corporate consumers and the tendency of consumers to purchase products based on least initial cost rather than the least life-cycle cost.

Further barriers relate to public policies and institutions and include the lack of attractive financing for renewable energy measures and regulations that directly or unwittingly discourage renewable energy uptake. Specific barriers include: lack of competitiveness as a result of high upfront costs and relatively long payback periods; high investment costs (due to low energy density) and frequently excessive profit anticipation of investors make financing of renewable technologies difficult; lack of financing sources and/or of access to appropriate financing mechanisms; high discount rates which disadvantage projects with high capital costs but low running costs such as solar thermal and other renewable energy technologies; higher transaction costs (information, procurement, installation works, etc.) than conventional thermal energy systems, for example an electric geyser versus solar water heater.

\section{CONCLUSION}

Nigeria is blessed with abundant resources of energy. There is the urgent need to encourage the evolvement of solar thermal energy technologies. Its adoption especially for rural development will surely lead to reduced internal consumption of petroleum products. The major advantages of the solar thermal energy technologies include the simplicity of the technologies, ease of maintenance as well as their enhanced environmental friendliness over fossil fuel systems. There is clear evidence of the use of renewable energy technologies at the moment. However, there is the necessity to increase the use of the system, especially for rural development. In this regard there is the urgent need for more support of research development, demonstration and diffusion activities in the existing research centers as well as identified groups in other institutions. Indeed energy extension outfits will have to be established.

All the aforementioned policy measures and implementation strategies to promote the use of the sustainable energy systems and practices can only be realized with strengthened energy institutions. 


\section{REFERENCES}

ECN, 2003. National Energy Policy. Energy Commission of Nigeria, Federal Republic of Nigeria, Abuja, Nigeria. ECN, 2004. Energy demand projection document, section 4.4.2. Analysis and Comparison of Sectoral Energy Demand, pp: 115-128. http://www.energy.gov.ng/ index.php.

European Commission, 2001. Future needs and challenges for non-nuclear energy research in the European Union. Discussion Paper, Energy, Environment and Sustainable Development, Nigeria. http://ec.europa. eu/research/energy/pdf/expert_workshops.pdf.
Fagbenle, R.L., 1992a. A comparative study of some simple models for global solar irradiance in Ibadan, Nigeria. Int. J. Energy Res., 16: 583-596.

Fagbenle, R.L., 1992b. Solar irradiation iso-lines for rapid design of solar systems in Nigeria. RERIC Int. Energy J., 14: 37-48.

Manohar, K. and A.A. Adeyanju, 2009. Hydro power energy resources in Nigeria. J. Eng. Applied Sci., 4: 68-73.

Yumkella, K.K., UNIDO, RIDC andECN, 2003. Renewable Energy for Rural Industrialization and Development in Nigeria. United Nations Industrial Development Organization, Regional Industrial Development Centre, Nigeria, Pages: 97. 